Nadwa | Jurnal Pendidikan Islam

Vol. 9, Nomor 2, Oktober 2015

\title{
Pembaharuan Pendidikan Islam Konsep Pendidikan Tinggi Islam Menurut Pemikiran Fazlur Rahman
}

\author{
Aan Najib \\ Universitas Islam Negeri Sunan Ampel Surabaya \\ Email: aannajib@gmail.com
}

\begin{abstract}
Fazlur Rahman idea of renewal Islamic college is lead to improvement of the current Islamic education. The final conclusion of this paper is (1). the formulation of thought the concept of Islamic higher education to be developed must be built on a solid paradigm spiritually, superior intellectually, and graceful morally with the Qur'an as a first reference and foremost. (2) offer a curriculum that are open to the studies of philosophy and social-science. (3) If the Islamic college in Indonesia is willing to follow the educational Fazlur Rahman thinking, motivation Indonesian Muslims to the development of science will be stronger, the dichotomy of science will be increasingly eroded.
\end{abstract}

Keyword : Renewal, the Islamic college, Fazlur Rahman

\begin{abstract}
Abstrak
Gagasan Fazlur Rahman tentang pembaharuan pendidkan tinggi Islam sangat berhubungan dengan peningkatan pendidikan Islam masa kini. Kesimpulan akhir dari makalah ini adalah (1) formulasi pemikiran tentang konsep pemikiran mengenai pendidikan tinggi Islam yang akan dikembangkan harus dibangun di atas paradigma spiritual yang solid, unggul secara intelektual, dan anggun secara moral sesuai dengan Al-Qur'an sebagai rujukan pertama dan terutama. (2) kurikulum yang terbuka untuk studi filsafat dan ilmu sosial. (3) Jika perguruan tinggi Islam di Indonesia bersedia mengikuti pemikiran pendidikan Fazlur Rahman, maka keinginan umat Islam Indonesia untuk pengembangan ilmu pengetahuan akan lebih kuat, dikotomi ilmu akan semakin terkikis.
\end{abstract}

Kata kunci: Pembaharuan, Pendidikan Tinggi Islam, Fazlur Rahman. 


\section{Pendahuluan}

Fazlur Rahman sebagai seorang tokoh intelektual Muslim, memiliki latar belakang yang menarik. Fazlur Rahman, memiliki latar belakang tradisi keilmuan madrasah India - Pakistan yang tardisional dan keilmuan Barat yang liberal. Keduanya berpengaruh dalam membentuk intelektualismenya. Ahmad Syafi'i Ma'arif, yang pernah berguru kepadanya, menyatakan bahwa dalam diri gurunya, Fazlur Rahman, terkumpul ilmu seorang 'alim yang 'alim dan ilmu seorang orientalis yang beken. ${ }^{1}$

Fazlur Rahman menyuguhkan analisis perkembangan pendidikan tinggi Islam dan merumuskan alternatif metodologi pemikiran keislaman, sebagai rumusan jalan keluar dari seluruh kritisisme atas sejarah pemikiran keislaman. Krisis metodologi tampaknya sangat disadari oleh Fazlur Rahman sebagai penyebab kemunduran pemikiran Islam, karena alternatif metodologi dipandangnya sebagai titik pusat penyelesaian krisis intelektualisme Islam. Implikasi dari alternatif metodologis ini, menurutnya merupakan proyek besar ummat Islam yang mengarah pada pembaharuan pemikiran Islam. Fazlur Rahman menyadari bahwa proyek besar tersebut selain memerlukan waktu yang panjang juga memerlukan sarana penunjuang. Menurutnya sarana penunjuang yang dimaksud tiada lain adalah sistem pendidikan Islam. Sistem pendidikan harus terlebih dahulu dimodernisasi, membuatnya mampu menyokong produktivitas intelektual Islam dengan cara menaikkan standar-standar intelektualnya ${ }^{2}$

Kesadaran Fazlur Rahman terhadap pendidikan sebagai sarana utama penunjang pembaharuan, mendorongnya terjun dalam kritisme sistem pendidikan Islam yang berkembang pada periode kemunduran dan pada awal pembaharuan atau zaman modern ${ }^{3}$ Fazlur Rahman, menyusun sebuah karya umum yang secara historis mengemukan sistem pendidikan Islam pada abad pertengahan berikut kelebihan-kelebihan dan kekurangan-kekurangan utamanya, dan mengenai upaya-upaya modernisasi yang dilakukan sekitar abad

${ }^{1}$ Ahmad Syafi'i Ma'arif,: Fazlur Rahman, al-Qur'an dan Pemikirannya dalam Islam, Edisi Indonesia, (Bandung: Pustaka, ,1984) hlm.vi.

${ }^{2}$ Fazlur Rahman, Islam, Anchor Books, New York, 1968, dilengkapi edisi The Chicago University, 1979,. Tej. Ahsin Mohammad, (Bandung: Pustaka, cetakan III,1997) hlm. 134.

${ }^{3}$ Ghufron A. Mas'adi, Pemikiran Fazlur Rahman tentang Metodologi Pembaharuan Hukum Islam, (Jakarta: Raja Grafindo Persada,1997) , hlm. 23 
yang lalu. Kemudia Fazlur Rahman membangun suatu pemikiran pendidikan tinggi Islam yang disebut sebagai "intelektualisme Islam".

Konsep pendidikan tinggi Islam yang dikemukakan oleh Fazlur Rahman merupakan masalah yang menarik dan urgen untuk dibahas, karena penyelenggaran pendidikan tinggi Islam sekarang ini mengalami proses dikotomi yaitu menerapkan metode dan muatan pendidikan barat dengan menambah beberapa mata pelajaran agama Islam dengan metode dan muatan Islami yang berasal dari zaman klasik yang belum dimodernisasi secara mendasar. Penyelenggaran pendidikan Islam belum mengacu dan mengantisipasi zaman yang sedang berubah, tetapi hanya menjaga dan melestarikan segala warisan yang bersifat klasik. Dari pemikiran Fazlur Rahman tersebut, timbul pertanyaan, apa yang menjadi perhatian utamanya? Posisi pemikirannya di antara pemikir-pemikir kontemporer Islam lainnya? Untuk menjawab pertanyaan-pertanyaan tersebut, tulisan ini mencoba mencermati dan menggali gagasan dan pemikiran Fazlur Rahman tentang konsep pendidikan Islam dan pendidikan tinggi Islam.

\section{Tradisi Intelektual Islam}

Dalam tradisi intelektual Islam, pendidikan telah lama dikenal yaitu sejak awal Islam. Pada masa awal, pendidikan idektik dengan upaya da'wah Islamiyah, karena itu pendidikan berkembang sejalan dengan perkembangan agama itu sendiri. Fazlur Rahman ${ }^{4}$, menyatakan kedatangan Islam membawa untuk pertama kalinya suatu instrumen pendidikan tertentu yang berbudayakan agama, yaitu alQur'an dan ajaran-ajaran Nabi. Tetapi, perlu dipahami bahwa pada masa awal perkembangan Islam, tentu saja pendidikan formal yang sistematis berlum terselenggara. Pendidikan yang berlangsung dapat dikatakan bersifat informal, dan inipun lebih berkait dengan upaya da'wah Islamiyah-penyebaran, penanaman dasar-dasar kepercayaan, dan ibadah Islam. Dalam kaitan itulah dapat dipahami kenapa proses pendidikan Islam pertama kali berlangsung di rumah, dan yang paling terkenal dar al-Arqam, dan ketika masyarakat Islam sudah terbentuk, pendidikan diselenggarakan di mesjid dan

${ }^{4}$ Fazlur Rahman, Islam.........: hlm. 263 
proses pendidikan pada kedua tempat ini dilakukan dalam halaqah, lingkaran belajar ${ }^{5}$

Tradisi belajar yang telah ada pada masa Nabi terus berkembang pada masa-masa sesudahnya, dan sebagaimana tercacat dalam sejarah bahwa puncak kemajuannya tercapai pada masa khalifah Harun al-Rasyid dan al-Makmun yang berpusat di Bagdad, dan pada masa kejayaan 'Usmaniyah di Spanyol dan Cordova yang berlangsung sekitar delapan abad [711-1492 M] ${ }^{6}$ kemudian sistem pendidikan Islam itu diperluas dengan sistem madrasah yang mencapai puncaknya pada Madrasah Nidzamiyah yang didirikan di Bagdad oleh Nizam al-Mulk ${ }^{7}$ Pendidikan Islam pada waktu itu telah melahirkan cendekiawan-cendekiawan Muslim yang berkaliber dunia, yang dikenal sampai sekarang ini, maka secara epistemologi Noeng Muhajir sangat argumentatif berkesimpulan bahwa Yunani adalah induk ilmu murni dan Islam adalah induk teknologi ${ }^{8}$

Fazlur Rahman, menyatakan bahwa pada awal mula tersebarnya ilmu pengetahuan Islam berpusat pada individu-individu dan bukannya sekolah-sekolah. Kandungan pemikiran Islam juga bercirikan usaha-usaha individual yaitu tokoh-tokoh istimewa tertentu, yang telah mempelajari hadits dan membangun sistem-sistem teologi dan hukum mereka sendiri di seputarnya, kemudian menarik murid-murid dari daerah lain yang mau menimba ilmu pengetahuan dari mereka. Ciri utama pertama dari ilmu pengetahuan tersebut adalah pentingnya individu guru, karena sang guru setelah memberikan pelajaran seluruhnya, secara peribadi memberikan suatu sertifikat (ijazah) kepada muridnya untuk mengajar. Dengan demikian, dapat dikatakan bahwa pada akhir abad pertengahan, mayoritas ilmuwan-ilmuwan yang termasyhur dan berkaliber dunia bukanlah produk madrasah-madrasah, tetapi merupakan bekas-bekas murid informal dari guru-guru individual tertentu. Sebagai contoh, bila akan menulis riwayat pemikir-pemikir yang besar dan orisinal

5 Azyumardi Azra, Pendidikan Tinggi Islam dan Kemajuan Sain (sebuah Pengantar), Pengantar dalam buku ; Charles Michael Stanton, Higher Learning in Islam, Terj. H.Afandi dan Hasan Asari, (Jakarta: Logos Publishing House, 1994), hlm.. 21

${ }^{6}$ Hasan Langgulung, Manusia dan Pendidikan Suatu Analisis Psikologi dan Pendidikan, (Jakarta: Pustaka al-Husna, 1986), hlm. 13

${ }^{7}$ Muhammad Munir Mursi, Al-Tarbiyah al-Islamiyah: Ushuluha wa tathawwuruha fi al-Bilad al- 'Arabiyah: (Beirut: Dar al-Fikr,1975), hlm. 98.

${ }^{8}$ Hamid Hasan Bilgrami dan Sayid Ali Asyraf, Universitas Islam, terj. Ahmad, (Yogyakarta, Tiara Wacana , 1989), hlm..xi 
dalam Islam, pasti tak akan banyak menemukan totoh-tokoh keluaran madrasah.

Tampaknya, madrasah belum dapat memproduk ilmuwanilmuwan termasyhur, karena itu Fazlur Rahman, menyatakan sistem madrasah yang secara luas didasarkan pada sponsor dan kontrol negara, umumnya telah dipandang sebagai sebab kemunduran dan kemacetan ilmu pengetahuan dan kesarjanaan Islam. Tetapi menurutnya madrasah dengan kurikulumnya yang terbatas, hanyalah gejala, bukan sebab sebenarnya dari kemunduran ini, walaupun sebenarnya persoalan tersebut mempercepat dan melestarikan kemacetan tersebut. Selanjutnya, Fazlur Rahman menyatakan sebenarnya penurunan kualitas ilmu pengetahuan Islam adalah berasal dari kekeringan yang gradual dari ilmu-ilmu keagamaan, karena pengucilannya dari kehidupan intelektualisme awam yang juga kemudian mati ${ }^{9}$

Berdasarkan pemikiran di atas, Fazlur Rahman menyatakan bahwa berkembangnnya ilmu dan semangat ilmiah dari abad ke-9 sampai abad ke-13 di kalangan umat Islam berasal dari terlaksananya perintah al-Qur'an untuk mempelajari alam semesta, karena karya Allah tersebut memang diciptakan untuk kepentingan manusia,. Pada abad-abad pertengahan akhir, semangat penyelidikan di dunia Islam mengalami kemacetan dan merosot, sedangkan dunia Barat telah melaksanakan kajian-kajian yang sebagian besar dipinjam dari ilmuan-ilmuan Muslim, sehingga mereka menjadi makmur, dan maju bahkan menjajah negeri-negeri Muslim. Dengan dasar ini, maka menurut Fazlur Rahman, umat Islam dalam mempelajari ilmu baru dari dunia Barat yang maju, berarti meraih kembali masa lampau mereka dan sekaligus untuk memenuhi sekali lagi perintah-perintah al-Qur'an yang terlupakan ${ }^{10}$

\section{Esensi Pendidikan Islam}

Esensi "Pendidikan Islam", menurut Fazlur Rahman tidaklah memaksudkan perlengkapan dan peralatan-peralatan fisik atau kuasi-fisik pengajaran seperti buku-buku yang diajarkan ataupun struktur eksternal pendidikan, tetapi adalah apa yang menurut Fazlur Rahman sebagai "intelektualisme Islam", dan bagi Fazlur Rahman inilah esensi pendidikan tinggi Islam. Intelektualisme Islam

${ }^{9}$ Fazlur Rahman, Islam...... hlm..269-271

${ }^{10}$ Syafi'i Ma'arif, Fazlur Rahman. hlm..6 
merupakan pertumbuhan suatu pemikiran Islam yang asli dan memadai, yang harus memberikan kreteria untuk menilai keberhasilan atau kegagalan sebuah sistem pendidikan Islam. Perumusan pemikiran pendidikan tinggi Islam haruslah didasarkan kepada metoda penafsiran yang benar terhadap al-Qur'an. Mengapa alQur'an harus ditempatkan sebagai titik pusat intelektualisme Islam, jawabannya karena bagi Muslim, al-Qur'an adalah kalam Allah yang diwahyukan secara harfiah kepada Nabi Muhammad, dan barangkali tidak ada dokumen keagamaan lain yang dipegang seperti itu ${ }^{11}$

Dari pemikiran dan pandangan tersebut, Ahmad Syafii Maarif ${ }^{12}$ menyatakan jika proposisi Fazlur Rahman ini dapat diterima, maka paradigma baru pendidikan tinggi Islam haruslah tetap berangkat dari pemahaman yang benar dan cerdas terhadap Kitab Suci alQur'an , yang berfungsi sebagai petunjuk, pencerahan, penawar, sekalipun kemungkinan resikonya adalah bahwa beberapa bangunan pemikiran Islam klasik harus ditolak atau diperkarakan. Cara ini terpaksa ditempuh karena semua bangunan pemikiran tentang filsafat, teologi, sufisme, sistem hukum, moral, pendidikan, sosial budaya, dan politik, pasti dipengaruhi oleh suasana ruang dan waktu. Analog dengan ini, maka hasil pemikiran kitapun juga akan diperkarakan oleh generasi sesudah kita kalau ternyata hasil pemikiran itu dinilai telah kehilangan kesegaran dan elan vital untuk menjawab persoalan-persoalan zaman yang salalu berubah.

Lebih lanjut, Ahmad Syafii Maarif ${ }^{13}$ menyatakan bahwa salah satu penyebab tersungkurnya dunia Islam adalah karena pendidikan yang diselenggarakan tidak lagi mengacu kepada dan mengantisipasi zaman yang sedang berubah dan bergulir. Umat sibuk "bernyanyi" di bawah payung kebesaran masa lampau dengan sistem politik dinasti yang otoriter. Proses penyadaran kembali terhadap tanggungjawab global umat ternyata memakan tempo yang lama sekali, karena pendidikan yang diselenggarakan sangat konservatif dalam arti menjaga dan melestarikan segala yang bersifat klasik. Daya kritis dan inovatif hampir-hampir lenyap samasekali dari

11 Fazlur Rahman, Islam and Modernity, Transformation of an Intellectual Tradition, The University of Chicago, Chicago, 1982., terj. Ahsin Mohammad, (Bandung, Pustaka, 1985), hlm.1

${ }^{12}$ Fazlur Rahman, Islam...... hlm. 1

${ }^{13}$ Fazlur Rahman, Islam...., hlm. 3 
ruangan madrasah, pondok, dan lembaga pendidikan lainnya di seluruh negeri Muslim.

Berkenaan dengan pemikiran di atas, Fazlur Rahman, menawarkan perumusan pemikiran konsep pendidikan tinggi Islam haruslah didasarkan dan berangkat dari pemahaman yang benar dan pendalaman terhadap al-Qur'an, yang berfungsi sebagai petunjuk atau inspirasi bagi generasi muda Islam. Disertasi 'Abdul Fazlur Rahman Salih, menyatakan bahwa pendidikan berdasarkan alQur'an, karena "cara hidup Islami ditentukan dalam al-Qur'an; mengikuti ini, maka fondasi-fondasi teori pendidikan Islam pada dasarnya diambil dari al-Qur'an. Pendekatan apa pun yang mengabaikan fakta fundamental ini pasti akan menghasilkan persepsipersepsi yang tidak akurat"14

\section{Pendidikan Tinggi Islam}

Fazlur Rahman menyatakan terdapat kesadaran yang luas dan kadang-kadang mendalam akan adanya dikotomi dalam pendidikan, namum semua upaya ke arah integrasi yang asli sejauh ini, pada umumnya tidak membuahkan hasil. Fazlur Rahman mengatakan perlu mencermati ciri-ciri pokok dan upaya-upaya yang dilakukan untuk memperbaharui pendidikan Islam. Pada dasarnya ada dua segi orientasi pembaharuan, salah satu pendekatannya yaitu menerima pendidikan sekuler modern sebagaimana telah berkembang secara umumnya di Barat dan mencoba untuk "mengislamkan"nya - yakni mengisinya dengan konsep kunci tertentu dari Islam. Pendekatan ini memiliki dua tujuan: Pertama, membentuk watak pelajar-pelajar/mahasiswa-mahasiswa dengan nilai Islam dalam kehidupan dan masyarakat, dan kedua, untuk memungkinkan para ahli yang berpendidikan modern untuk menamai bidang kajian masing-masing dengan nilai-nilai Islam pada perangkat-perangkat yang lebih tinggi; menggunakan perspektif Islam, untuk mengubah - di mana perlu - baik kandungan maupun orientasi kajian-kajian mereka. Kedua tujuan ini berkaitan erat dalam arti bahwa pembentukan watak dengan nilai-nilai Islam yang secara wajar dilakukan terutama pada pendidikan tingkat pertama ketika pelajar-pelajar masih dalam usia muda dan mudah menerima kesan ${ }^{15}$

14 Abdul Fazlur Rahman Salih 'Abdullah, Educational Theory: a Qur'anic Qutlook., dalam A.Syafi'i Ma'arif, Al-Quran ..., hlm. 8

${ }^{15}$ Fazlur Rahman, Islam...... hlm. 156 
Pandangan lain yang sedikit berbeda dengan Fazlur Rahman, yaitu Syed Sajjad Husain dan Syed Ali Ashraf ${ }^{16}$ yang menyatakan bahwa, pada saat sekarang ini ada dua sistem pendidikan. Pertama, sistem pendidikan tradisional, yang telah membatasi dirinya pada pengetahuan klasik, belum menunjukkan minat yang sungguhsungguh pada cabang-cabang pengetahuan baru yang telah muncul di dunia Barat atau pada metode-metode baru untuk memperoleh pengetahuan yang penting dalam sistem pendidikan Barat. Sistem ini memang berguna untuk pengetahuan teologi klasik, tapi para ahli teologi klasik yang dilahirkan dari sistem ini pun tidak cukup mendapat bekal pengetahuan intetelektual atau suatu metoda guna menjawab tantangan-tantangan dari peradaban teknologi modern yang tak mengenal Tuhan. Kedua, sistem pendidikan yang didatangkan ke negeri-negeri Muslim, yang disokong dan didukung sepenuhnya oleh semua pemegang pemerintah, adalah sistem yang dipinjam dari dunia Barat. Puncak dari sistem ini adalah universitas modern yang bersifat sekuler keseluruhannya dan karena tidak mengindahkan agama dalam pendekatannya terhadap pengetahuan. Orang-orang yang didik melalui sistem pendidikan baru ini yang dikenal sebagai pendidikan modern, pada umunya tidak menyadari akan tradisi dan warisan klasik mereka sendiri.

Selain kedua sistem ini, diciptakan pula sistem pendidikan alternatif, yaitu sistem ketiga yang mancakup sistem pendidikan terpadu, tetapi menurut Sajjad Husain dan Ali Ashraf, kepaduan kedua sistem ini bukanlah merupakan suatu proses yang gampang, karena ada kekhawatiran sistem perpaduan ini menuntut penghapusan total atas sistem pendidikan tradisonal, atau penurunan keududukan dari sistem itu sampai sedemikian rupa sehingga orang-orang akan memandang rendah padanya, atau tidak menghargai mereka yang ingin mengambil spesialisasi dalam cabang itu. Dengan demikian dualisme sistem pendidikan Islam dan pendidikan umum yang memisahkan kejian-kajian agama dengan ilmu pengetahuan, yang dikotomi ini menyebabkan pendidikan Islam belum mampu melahirkan mujtahid-mujtahid besar.

Pendidikan Islam merupakan lembaga pendidikan ilmu-ilmu keislaman efek pembaharuannya baru dirasakan dalam lapangan

${ }^{16}$ Syed Sajjad Husein dan Syed Ali Ashraf, Crisis Muslim Education, (Jeddah Saudi Arabia : Hodder and Stoughton King Abdulaziz University, First Published 1979) terj. Fazlur Rahmani Astuti, (Bandung: Risalah, 1986), hlm. 21-22 
reorganisasi, dan tidak dalam kandungan ilmu-ilmu Islam seperti teologi dan filsafat. Pendidikan Tinggi Islam belum mampu membangun paradigma baru yang tetap berangkat dari pemahaman al-Qur'an, sehingga mampu melahirkan apa yang disebut dengan "intelektualisme Islam". Tampaknya bagi Fazlur Rahman, dikotomi tidak merupakan alasan, karena salah satu tawarnnya adalah menerima pendidikan sekuler modern yang berkembang di dunia Barat, dengan mengisinya dengan konsep-konsep kunci tertentu dari Islam, yang mewarnai bidang-bidang kajian tingkat tinggi dengan nilai-nilai Islam. Masalah pokok yang dihadapi adalah bagaimana "memodernisasi" pendidikan Islam, yakni membuatnya mampu untuk produktivitas intelektual Islam yang kreatif dalam semua bidang usaha intelektual bersama-sama dengan keterikatan yang serius kepada Islam ${ }^{17}$

Fazlur Rahman, melihat ada dua arah upaya pembaharuan yang sedemikian jauh telah dilakukan. Pertama, pembaharuan ini telah terjadi hampir seluruhnya dalam kerangka pendidikan tradisional sendiri. Perubahan ini sebagian besar digerakkan oleh fenomena pembahruan pra-modernis. Pembaharuan ini telah cenderung "menyederhanakan" silabus pendidikan tradisional, yang dilihatnya sarat dengan materi-materi "tambahan yang tak perlu" seperti theologi zaman pertengahan, cabang-cabang filsafat tertentu (seperti logika). Kedua, suatu keragaman perkembangan telah terjadi, yang bisa diringkas dengan mengatakan bahwa ragam-ragam perkembangan tersebut semuanya mencerminkan upaya untuk menggabungkan dan memadukan cabang-cabang pengetahuan modern dengan cabang-cabang pengetahuan lama.

Fazlur Rahman, mencermati percobaan-percobaan pembaruan yang dilaukan oleh al-Azhar Mesir dan sistem baru pendidikan Islam diperkenalkan di Turki sejak akhir tahun-tahun 1940-an. AlAzhar mempunyai jejak tradisi ilmu-ilmu keislaman zaman pertengahan. Maka dapat dipahami bila sifat konservatifnya dalam lapangan kajian-kajian keagamaan masih sangat kuat, sehingga konsekuensinya, kajian-kajian modern seperti filsafat, sosiologi dan psikologi tanpaknya tidak mempunyai dampak yang mendalam, karena kajian-kajian modern tersebut pada pokoknya ditempatkan di belakang ilmu-ilmu pengetahuan tradisional. Sebaliknya di Turki 
dalam upaya pembaruannya, pendidikan tradisional telah dimusnahkan sama sekali, pendidikan agama diperkenalkan lagi dalam keadaan baru, sementara disiplin-disiplin modern hampir berada pada taraf yang sama dengan di sekolah-sekolah umum di seluruh negeri-negeri berkembang. Turki menafsirkan warisan intelektual Islam zaman pertengahan dan memberinya sebuah bentuk yang baru $^{18}$

Kemudian Fazlur Rahman, juga menilai modernisasi al-Azhar, sebagai sampel lembaga pendidikan ilmu-ilmu keislaman, sekalipun telah diupayakan semenjak abad kesembilan belas, dapat dikatakan tak berubah dalam prosisi intelektual - spiritualnya. Namun menurut Fazlur Rahman, efek pembaruan pada al-Azhar baru dirasakan dalam lapangan reorganisasi, sistem ujian, dan pengenalan pokok-pokok kajian baru, dan tidak dalam kandungan ilmu-ilmu Islam inti seperti teologi dan filsafat. Fazlur Rahman, menilai tesa yang dikemukakan oleh 'Abdul Muta'al al-Sha'idi yang menyatakan bahwa pendidikan yang diberikan di al-Azhar tidak bisa melahirkan mujtahid-mujtahid besar, yakni orang-orang yang mempunyai kemampuan dan kehendak untuk melakukan pemikiran baru dalam berbagai aspek pemikiran Islam, sebagai sebuah "truisme" ${ }^{19}$ Dalam perkembangan pemikirannya, Fazlur Rahman, tidak hanya melihat perubahan sistem pendidikan di Turki, Mesir dan Pakistan, tetapi juga melihat percobaan pembaruan yang dilakukan di Indonesia. Upaya pembaruan yang dilakukan merupakan penggabungan ilmuilmu modern dengan ilmu-ilmu tradisional. Pembaruan yang dilakukan meliputi beberapa aspek yaitu sistem, metode dan materi. Segi sistem mulai dilaksanakannya sistem klasikal di lembaga-lembaga pendidikan Islam. Pada segi metode tidak lagi semata-mata memakai sorogan, wetonan dan hafalan, akan tetapi beberapa metode mengajar lainnya mulai diperkenalkan. Sedangkan pada segi materi mulai diperkenalkan mata pelajaran umum pada lembaga-lembaga pendidikan Islam.

Upaya pembaruan pendidikan Islam di Indonesia, sebagai usaha untuk mengejar ketertinggalan di bidang pendidikan dan pengajaran, menyebabkan orientasi pendidikan dan pengajaran Islam di Indonesia mengalami perubahan. Namun, menurut Fazlur Rahman, Indonesia sebagaimana negara-negara Muslim lainnya menghadapi masalah pokok dalam pembaruan pendidikan Islam. Masalah itu

${ }^{18}$ Fazlur Rahman, Islam .... hlm. 165-166

${ }^{19}$ Fazlur Rahman, terj. Ahsin Mohammad, Islam ..... hlm. 117-119 
meneurutnya adalah "kelangkaan tenaga guru yang memadai untuk mengajar dan riset, dan bagaimana memproduksi tenaga seperti itu. Karenanya, tak bisa dihindarkan lagi dilakukannya percobaan-percobaan dalam penyempurnaan materi-materi pelajaran Islam klasik dengan pelajaran-pelajaran modern. Kedua mata pelajaran itu dicampurkan dalam berbagai proporsi, tergantung apakah lembaga pendidikan yang bersangkutan termasuk dalam sistem pendidikan umum. Pada tingkat pendidikan tinggi, melalui percobaan dengan berbagai lembaga yang disebut universitas-universitas Islam di Jakarta dan Yogayakarta yang akan menghasilkan sarjana-sarjana ilmu keislaman. Kurikulum yang dipakai tampaknya mengikuti pola empat fakultas di al-Azhar yaitu teologi (ushuluddin) dan syari'ah atau hukum Islam, pendidikan (tarbiyah) dan adab, atau humanika Islam, dengan penekanan khusus pada bahasa Arab.

Fazlur Rahman, mempunyai harapan besar untuk Indonesia. Ia menyatakan walaupun sekarang ini pendidikan Islam di Indonesia sangat bergantung pada model al-Azhar, pasti akan mampu mengembangkan suatu tradisi Islam pribumi yang bermakna, yang akan benar-benar bersifat Islami dan kreatif ${ }^{20}$, Karena Fazlur Rahman memandang Indonesia dan Turki adalah dua negara yang mengembangkan pemikiran liberal.

Pandangan Fazlur Rahman tentang kurikulum, tampaknya kurikulum pendidikan Islam tingkat tinggi yang dikehendaki oleh Fazlur Rahman adalah kurikulum terbuka bagi kajian-kajian filsafat dan sain-sain sosial. Fazlur Rahman sangat menekankan peranan filsafat sebagai kegiatan kritis analitis dalam melahirkan gagasangagasan yang bebas. Dalam hal ini menurutnya, filsafat berfungsi menyediakan alat-alat intelektual bagi teologi dalam menjalankan tugasnya untuk "membangun suatu pandangan dunia berdasarkan al-Qur'an". Selain itu, Fazlur Rahman juga memandang penting keterlibatan sains-sains sosial, karena sains-sains tersebut merupakan produk perkembangan modern yang berguna dalam memberikan keterangan kondisi obyektif suatu kehidupan dunia yang menjadi obyektif pengejawantahan ajaran-ajaran al-Qur'an ${ }^{21}$

Selain Fazlur Rahman, Hamid Hasan Bilgrami dan Sayid Ali Asyraf dalam bukunya Konsep Universitas Islam yang disimpulkan oleh Noeng Muhajir, menyatakan bahwa pembahasan dalam buku

${ }^{20}$ Fazlur Rahman, Islam.... hlm. 151-152

${ }^{21}$ Fazlur Rahman, Islam...., hlm. 157-160 
ini menawarkan tiga rekonstruksi dalam upaya Islamisasi universitas. Pertama, rekonstruksi tentang konsep ilmu. Yaitu menawarkan memasukkan ilmu-ilmu naqliyyah, seperti al-Qur'an, Hadits, Fiqh, Tauhid, dan Metafisika sebagai mata kuliah dasar umum elektif bagi mahasiswa, melandasi disiplin ilmunya masing-masing yang aqliyyah sifatnya. Kedua, rekonstruksi kelembagaan, yaitu : menjadikan lembaga pengembangan studi ilmu-ilmu naqliyyah sebagai bagian dari universitas. Ketiga, rekonstruksi atau lebih tepatnya pengembangkan kepribadian individual, mulai dari dosennya sampai ke alumninya. Menurut Noeng Muhajir, rekonstruksi pertama banyak tergantung kepada pemegang otoritas akademik perguruan tinggi yang bersangkutan. Rekonstruksi kedua lebih banyak tergantung kepada pemegang otoritas kelembagaan perguruan tinggi yang bersangkutan. Rekonstruksi ketiga memerlukan evolusi panjang bertahun-tahun, yang peningkatan kualitasnya merupakan pangaruh timbal balik dengan keberhasilan rekonstruksi kedua dan pertama $^{22}$

Jadi, menurut Fazlur Rahman, pada pokoknya seluruh masalah "modernisasi" pendidikan Islam, yakni membuatnya mampu untuk produktivitas intelektual Islam yang kreatif dalam semua bidang usaha intelektual bersama-sama dengan keterkaitan yang serius kepada Islam. Modernisasi pendidikan Islam bukan pada perlengkapan dan peralatan-peralatan fisik pengajaran seperti buku-buku, tetapi upaya modernisasi lebih pada membangun intelektualisme Islam. Untuk itu, perumusan pendidikan tinggi Islam haruslah didasarkan pada metode penafsiran yang benar terhadap al-Qur'an, karena al-Qur'an harus ditempatkan sebagai titik intelektualisme Islam. Pemahan yang benar dan mendalam terhadap al-Qur'an yang berfungsi sebagai petunjuk dan inspirasi bagi generasi muda Islam. Kemudian kurikulum yang tawarkan adalah kurikulum terbuka bagi kajian-kajian filsafat dan sain-sain sosial. Fazlur Rahman menekankan peranan filsafat sebagai kegiatan kritis analitis dalam melahirkan gagasan-gagasan yang bebas, kretaif beradasarkan alQur'an.

${ }^{22}$ Hamid Hasan Bilgrami dan Sayid Ali Asyraf, Universitas... hlm. X- 


\section{Aplikasi Pemikiran Fazlur Rahman tentang Pendidikan di Indonesia}

Pendidikan Islam di Indonesia dapat dibedakan ke dalam dua tingkatan, yakni pendidikan dasar-menengah dan pendidikan Tinggi Islam. Kemudian pendidikan dasar-menengah dibedakan lagi menjadi tiga yaitu pesantren, sekolah dan madrasah. Masing-masing memiliki keunggulan dan kelemahan. Pada umumnya pesantren unggul dalam bidang ilmu agama, tetapi lemah dalam ilmu umum, sebaliknya sekolah lemah dalam ilmu agama tetapi unggul di bidang ilmu umum. Madrasah diselenggarakan untuk menampung keunggulan pesantren dan sekolah, di samping untuk menghilangkan kelemahan dari keduanya, akan tetapi kenyataan menunjukkan sebaliknya.

Orientasi pendidikan Tinggi Islam seharusnya mengembangkan tiga perangkat manusia yang berupa akal, hati dan fisik (terutama panca indera) ${ }^{23}$ Pendidikan Tinggi Islam menurut Fazlur Rahman, sangat strategis untuk mengurai benang kusut krisis pemikiran dalam Islam yang berdampak pada stagnasi dan kemunduran peradaban umat Islam, yang darinya dapat diharapkan berbagai alternatif solusi atas problem yang dihadapi. Menurutnya pembaharuan Islam berorientasi pada kemajuan pendidikannya ${ }^{24}$

Menurut Fazlur Rahman, problem pendidikan yang paling mendasar adalah problem ideologi, maksudnya adalah ideologi Islam yang terkait dengan pentingnya ilmu, dimana Islam mengharuskan belajar dengan mengembangkan ilmu pengetahuan bagi semua pemeluknya sesuai dengan kemampuan mereka masingmasing. Umat Islam tidak dapat mengaitkan secara efektif pentingnya pengetahuan dengan orientasi ideologinya. Akibatnya adalah mereka tidak terdorong untuk belajar. Problem kedua adalah dualisme dalam sistem pendidikan umat Islam sebagai akibat dari adanya dikotomi ilmu dalam Islam. Pada satu sistem pendidikan Islam, mulai dari Madrasah sampai Perguruan Tinggi Islam, begitu tertinggal, sehinga produk dari keduanya tidak bisa mengikuti perkembangan zaman.

Secara mendasar, pembaharuan pendidikan Islam, menurut Rahman, dapat dilakukan dengan menerima pendidikan sekuler

${ }^{23}$ H.A.R. Tilaar, Beberapa Agenda Reformasi Pendidikan Nasional dalam Perspektif Abad 21 (Magelang: Tera Indonesia, 1998), hlm. 207-208

${ }^{24}$ Fazlur Rahman, Islam...., hlm..259-260 
modern, kemudian berusaha memasukinya dengan konsep-konsep Islam. Secara detail, menurutnya pembaharuan pendidikan Islam dapat dilakukan dengan cara:

a. Membangkitkan ideologi umat Islam tentang pentingnya belajar dan mengembangkan ilmu pengetahuan.

b. Mengintegrasikan ilmu (antara ilmu agama dan ilmu umum) kedalam pendidikan tinggi Islam di Indonesia untuk kemaslahatan umat manusia

c. Menyadari betapa pentingnya bahasa, kemudian mengembangkannya sebagai alat komunikasi, baik secar lisan maupun tulis.

d. Pembaharuan dibidang metode pendidikan Islam, yaitu beralih dari metode mengulang-ulang dan menghafal ke metode memahami dan menganalisis.

Kemudian, jika secara keseluruhan pemikiran Fazlur Rahman, disistematisasikan kedalam kurikulum yang unsur-unsurnya meliputi empat hal, yaitu tujuan, materi, metode, dan evaluasi. Mengenai tujuan pendidikannya ditemukan tiga macam tujuan yaitu:

a. Untuk mengembangkan manusia sedemikian rupa sehingga semua pengetahuan yang diperolehnya akan menjadi organ pada keseluruhan pribadi yang kreatif, yang memungkinkan manusia untuk memanfaatkan sumber alam untuk kebaikan umat manusia dan untuk menciptakan keadilan, kemajuan, dan keteraturan dunia.

b. Untuk menyelamatkan manusia dari diri sendiri oleh diri sendiri dan untuk diri sendiri.

c. Melahirkan ilmuwan yang padanya terintegrasi ilmu-ilmu agama dan ilmu-ilmu modern, yang ditandai dengan adanya sifat kritis dan kreatif.

Mengenai materinya, jika dikaitkan dengan klasifikasi ilmu pengetahuan, terdapat tiga macam yaitu pengetahuan tentang alam, pengetahuan tentang manusia, dan pengetahuan tentang sejarah. Akan tetapi, jika materinya disesuaikan dengan tujuan pendidikan yang ketiga, maka materinya terdiri dari, ilmu agama dan ilmu umum modern.

Mengenai metode pembelajarannya dilakukan dengan menekankan pada caara-cara memahami dan menganalisis materi pembelajaran. Metode pembelajarannya dapat juga dengan menerapkan teori a double movement. Gerak pertama terkait dengan mahasiswa, 
dan gerak kedua terkait dengan fungsi sosial dimasyarakat. Indikator yang dipakai dalam melakukan evaluasi adalah lahirnya ilmuwan yang kritis dan kreatif. $^{25}$

Selanjutnya, jika pemikiran pendidikan Fazlur Rahman dikaitkan dengan kurikulum berbasis kompetensi, maka akan kelihatan dengan jelas bahwa kompetensi yang akan dicapai dapat melahirkan ilmuwan yang memilki kompetensi secara terintegrasi antara ilmu agama dan ilmu umum modern dalam satu kesatuan pada ilmuwan tersebut. Materi pendidikannya terdiri dari ilmu agama Islam sebagai fondasinya dan ilmu umum modern sebagai spesialisasinya. Metode yang diterapkan adalah metode pembelajaran aktif.

\section{Kesimpulan}

Dari apa yang diuraikan di atas, Fazlur Rahman menawarkan (1) perumusan pemikiran konsep pendidikan tinggi Islam yang hendak dikembangkan haruslah dibangun di atas sebuah paradigma yang kokoh spiritual, unggul secara intelektual, dan anggun secara moral dengan al-Qur'an sebagai acuan yang pertama dan utama. (2) Tawaran kurikulum yang sifatnya terbuka bagi kajian-kajian filsafat dan sain-sain sosial. Fazlur Rahman, sangat menekankan peranan filsafat sebagai kegiatan kritis analtis dalam melahirkan gagasangagasan yang bebas. Dalam hal ini filsafat berfungsi menyediakan alat-alat intelektual bagi teologi dalam menjalankan tugasnya "membangun suatu pandangan dunia berdasarkan al-Qur'an" dan Fazlur Rahman memandang bahwa penting keterlibatan sains-sains sosial dalam disain pendidikan tinggi Islam.

\section{Kepustakaan}

Al-Jumbulati, Ali dan at-Tuwainisi, Abdul Futuh, 1991. Dirasatun Muqaaranatun fi al- Tarbiyyah al-Islamiyyah., terj. HM. Arifin, Rineka Cipta.

Azra, Azyumardi, dalam Marwan Saridjo, 1996, Bunga Rampai Pendidikan Agama Islam, Jakarta: Amissco.

1994, Pendidikan Tinggi Islam dan Kemajuan Sain (sebuah Pengantar), Pengantar dalam buku ; Charles Michael Stanton, Higher Learning in Islam, Terj. H.Afandi dan Hasan Asari, Jakarta: Logos Publishing House,

${ }^{25}$ Fazlur Rahman, “The Qur'anic Solution of Pakistan's Education Problems”, dalam Jurnal Islamic Studies (Vol. 6, no.4 1976), hlm.. 315-326 
Bilgrami, 1989, Hamid Hasan dan Asyraf, Sayid Ali, Universitas Islam, terj. Ahmad, Yogyakarta: Tiara Wacana.

Husein, Syed Sajjad dan Ashraf, Syed Ali, 1979, Crisis Muslim Education, Hodder and Stoughton King Abdulaziz University

Langgulung, Hasan, 1986, Manusia dan Pendidikan Suatu Analisis Psikologi dan Pendidikan, Jakarta: Pustaka al-Husna.

Maarif, Ahmad Syafii, 1997, Pengembangan Pendidikan Tinggi Post Graduate Studi Islam Melalui Paradigma Baru yang Lebih Efektif, Makalah Seminar. , 1984, Fazlur Fazlur Rahman, al-Qur'an dan Pemikirannya dalam Islam, Edisi Indonesia, Bandung: Pustaka.

Mas'adi, Ghufron A., 1997, Pemikiran Fazlur Fazlur Rahman tentang Metodologi Pembaharuan Hukum Islam, Jakarta : Raja Grafindo Persada.

Muhaimin, dkk., 1999. Kontraversi Pemikiran Fazlur Fazlur Rahman, Studi Kritis Pembaharuan Pendidikan Islam, Cirebon: Pustaka Dinamika,.

Natsir, M., 1973, Kapita Selecta, Jakarta: Bulan Bintang.

Rachman, Budhy Munawar, 1995, “ Dari Tahap Moral ke Periode Sejarah Pemikiran Neomodernisme Islam Di Indonesia", Dalam Jurrnal Ulumul Qur' an No 3. Vol. VI.

Rahman, Fazlur, 1968, Islam, New York, Anchor Books, dilengkapi 1979, edisi The Chicago University , 1982, Islam and Modernity, Transformation of an Intellectual Tradition, Chicago: The University of Chicago, terj. Ahsin Mohammad, 1985, Bandung : Pustaka ,1976, “ The Qur'anic Solution of Pakistan's Education Problems", dalam Jurnal Islamic Studies Vol 6, no.4

Sutrisno ,2000, “Epistimologi Pemikiran Fazlur Rahman Dan Implikasinya Dalam Pendidikan", Tesis, IAIN Sunan Kalijaga.

, 2006, Fazlur Rahman: Kajian Terhadap Metode, Epistimologi dan Sistem Pendidikan, Cet. I, Yogyakarta: Pustaka Pelajar.

Tilaar, H.A.R., 1998, Beberapa Agenda Reformasi Pendidikan Nasional dalam Perspektif Abad 21 Magelang: Tera Indonesia. 